\title{
Pengaruh yoga terhadap memori jangka pendek pada dewasa muda
}

\author{
Muhammad Ishak $^{1}$, Alvina ${ }^{2}$
}

\begin{abstract}
ABSTRAK
\section{LATAR BELAKANG}

Yoga adalah sebuah gaya hidup, suatu sistem pendidikan yang terpadu antara tubuh, pikiran, dan jiwa, dan merupakan metode yang berpengaruh dan dinilai efektif terhadap fungsi kognitif termasuk didalamnya fungsi memori jangka pendek. Yoga merangsang penurunan aktifitas saraf simpatis dan peningkatan akitifitas saraf parasimpatis yang berpengaruh pada penurunan hormon adrenalin, norepinefrin dan katekolamin serta vasodilatasi pada pembuluh darah yang mengakibatkan transpor oksigen ke seluruh tubuh terutama ke otak menjadi lancar sehingga dapat meningkatkan fungsi kognitif.
\end{abstract}

\section{METODE}

Penelitian ini menggunakan desain eksperimental metode potong lintang, menggambarkan fungsi memori jangka pendek dengan dan tanpa yoga. Penilaian memori jangka pendek menggunakan Digit Span Test di mana komponennya berupa deretan angka maju (Digit Forward) maupun mundur (Digit Backward). Penelitian ini melibatkan 47 subyek dewasa muda berusia 17-20 tahun dengan kriteria inklusi bersedia rutin mengikuti pelatihan yoga selama 21 hari dengan durasi 15-30 menit untuk sekali latihan yoga dan kriteria eklusi menderita suatu penyakit yang tidak dapat melakukan yoga, menderita gangguan pendengarandan mengalami penurunan kesadaran. Latihan yoga diberikan oleh instruktur yoga. Penilaian digit span dilakukan pada sebelum latihan yoga dan sesudah melakukan latihan yoga selama 21 hari. Analisis data dilakukan untuk menilai perbedaan skor fungsi memori jangka pendek masingmasing kelompok sebelum dan sesudah perlakuan menggunakan uji $\mathrm{T}$ Dependent/berpasangan atau uji Wilcoxon. Nilai $\mathrm{p}<0.5$ dianggap bermakna dengan 95\% interval kepercayaan.

\section{HASIL}

Terdapat $61.7 \%$ responden perempuan, $40.4 \%$ memiliki skor tinggi pada memori jangka pendek sebelum yoga dan 59.6\% memiliki skor tinggi sesudah yoga. Pengaruh yoga terhadap memori jangka pendek memiliki nilai $\mathrm{p}=0.000(\mathrm{p}<0.05)$. Hasil ini menunjukkan bahwa terdapat perbedaan skor memori jangka pendek sebelum dan sesudah melakukan yoga.

\section{KESIMPULAN}

Yoga memberikan dampak pada peningkatan digit span pada kelompok dewasa muda.

Kata kunci : yoga, memori jangka pendek, digit span test, dewasa muda

\author{
${ }^{1}$ Program Studi Kedokteran, \\ Fakultas Kedokteran, \\ Universitas Trisakti \\ ${ }^{2}$ Departemen Patologi Klinik, \\ Fakultas Kedokteran, \\ Universitas Trisakti
}

\section{Korespondensi:}

Alvina

Departemen Patologi Klinik, Fakultas Kedokteran, Universitas Trisakti, Jalan Kyai Tapa No. 260, Grogol, Jakarta Barat Email: dr.alvina@trisakti.ac.id; vina_march_dr@yahoo.com

J Biomedika Kesehat 2019;2(3):117123

DOI : 10.18051/JBiomedKes.2019.

v2.117-123

pISSN: 2621-539X / eISSN: 2621-5470

Artikel akses terbuka (open access) ini didistribusikan di bawah lisensi Creative Commons Attribution 4.0 International (CC-BY 4.0) 


\section{ABSTRACT}

\section{Effect of yoga on short-term memory in young adults}

\section{BACKGROUND}

Yoga is a lifestyle, an education system that is integrated between body, mind and spirit. Yoga is one method that influences and is considered effective on cognitive functions including short-term memory functions. Yoga stimulates decreased sympathetic nerve activity and increased parasympathetic nerve activity which influences the decrease in the hormones adrenaline, norepinephrine and catecholamines and vasodilation in blood vessels which results in oxygen transport throughout the body, especially to the brain, so that it can improve cognitive function. Because there are no studies in the young adult age group, researchers want to see the effect of yoga on short-term memory in young adults.

\section{METHODS}

This study uses an experimental cross-sectional design, describing short-term memory functions with and without yoga. Short-term memory assessment uses the Digit Span Test in which the components are in the form of a row of digits forward (Digit Forward) or backward (Digit Backward). This study involved 47 young adult subjects aged 17-20 years with inclusion criteria willing to routinely attend yoga training for 21 days with a duration of 15-30 minutes for one yoga practice and exclusion criteria suffered from an illness that could not do yoga, suffered from hearing loss and experienced a decrease in consciousness. Yoga exercises are given by yoga instructors. Digit span assessment is done before and after yoga practice for 21 days. Data analysis used to assess differences in the scores of short-term memory function of each group before and after treatment using the Dependent / paired $\mathrm{T}$ test or the Wilcoxon test. A value of $\mathrm{p}<0.05$ was considered significant with a $95 \%$ confidence interval.

\section{RESULT}

There were $61.7 \%$ of female respondents, $40.4 \%$ had high scores on short-term memory before yoga and $59.6 \%$ had high scores after yoga. The influence of yoga on short-term memory has a value of $p=0,000(p<0.05)$. These results indicate that there are differences in short-term memory scores before and after doing yoga.

\section{CONCLUSION}

Yoga has an impact on increasing digit span in young adult groups.

Keywords : yoga, short-term memory, digit span test, young adult

\section{PENDAHULUAN}

Memori atau daya ingat diartikan sebagai kemampuan individu dalam sebuah mekanisme yang dinamis berhubungan dengan pengambilan, penyimpanan informasi dan informasi tersebut dipanggil kembali untuk dapat dipergunakan beberapa waktu kemudian. ${ }^{(1,2)}$ Memori merupakan unsur inti dari perkembangan kognitif,.. ${ }^{(3,4)}$ Fungsi kognitif meliputi beberapa bagian yaitu fungsi reseptif, fungsi memori, fungsi berpikir dan fungsi ekspresif. ${ }^{(4)}$

Proses memori dibagi menjadi beberapa tahap, yaitu pengkodean, penyimpanan, penarikan dan pengingatan. ${ }^{(2)}$ Terdapat beberapa macam jenis pengingatan yang sering digunakan dalam eksperimen, yaitu serial recall, free recall, cued recall atau paired-associates recall, Pengenalan (recognition) dan Belajar kembali (relearning). Serial recall adalah pengingatan item dengan urutan yang tepat seperti urutan yang sebelumnya telah dipresentasikan. Free recall adalah pengingatan itemnya dengan urutan yang kita inginkan atau tidak seperti urutan yang sebelumnya telah dipresentasikan. Cued recall atau paired-associates recall adalah di mana item dipresentasikan dalam bentuk berpasangan yang selanjutnya hanya diberikan satu bagian pada pasangan tersebut, lalu kita mengingat pasangannya tersebut. Pengenalan (recognition) adalah di mana kita memilih atau mengidentifikasi pilihan berdasarkan pengalaman atau pembelajaran sebelumnya. Belajar kembali (relearning) merupakan jumlah yang diperlukan untuk mempelajari item sekali lagi yang pernah dipelajari sebelumnya di waktu tertentu. ${ }^{(2)}$

Memori jangka pendek yaitu proses penyimpanan memori sementara. Memori jangka pendek juga disebut sebagai ingatan primer. Memori jangka pendek ini mempunyai beberapa karakteristik yaitu memerlukan kesadaran atau melalui proses kognitif sadar, lamanya hanya 20 - 30 detik, maksimum 40 detik, kecuali jika dilakukan pengulangan untuk mempertahankan informasi tersebut, dan yang terakhir adalah jumlah materi yang disimpan hanya terbatas, umumnya sekitar 5-10 item atau $7 \pm 12$ item, item dapat berupa sesuatu yang sederhana seperti digit atau sesuatu yang lebih kompleks seperti kata. ${ }^{(5)}$ 
Memori jangka pendek ini sering diukur dalam rentang memori (memory span) dan terdapat jumlah item yang dapat diulang kembali dengan tepat sesudah satu penyajian tunggal. Materi yang dipakai berupa angka, huruf atau simbol yang dijadikan rangkaian urutan. Tes ini menggunakan angka dengan mengandalkan indra pendengaran yang disebut tes Digit Span. ${ }^{(6)}$

Faktor yang mempengaruhi memori jangka pendek antara lain adalah usia, genetik, nutrisi, kondisi psikis dan fisik. Pada tes memory span terdapat perbedaan rentang memori pada beberapa kelompok usia, di mana rentang memori meningkat sekitar 2 digit pada usia 2-3 tahun dan meningkat 5 digit pada usia 7 tahun. Hal tersebut menunjukan kelompok usia yang lebih tua memiliki memori yang lebih baik karena lebih sering mengulang informasi yang diterimanya dari pada anak usia yang lebih muda. Kecepatan dan efisiensi pemrosesan informasi juga berperan, terutama kecepatan dalam item-item ingatan yang bisa diidentifikasi. Pada lansia fungsi memori akan menurun akibat proses penuaan dari hippocampus. (4)

Abnormalitas kromosom dapat menghasilkan abnormalitas kognitif dan varian genetik mempengaruhi variasi kemampuan intelektual. Para peneliti dari NIH (National Instituesof Health) menemukan bahwa orang dengan gen met BDNF (Brain Derived Neurotrophic Factor) mempunyai nilai yang lebih buruk pada tes memori karena aktivasi hipokampus berbeda dari orang normal dan mempunyai kesehatan syaraf yang lebih buruk. ${ }^{(5)}$

Pemenuhan kebutuhan gizi merupakan hal yang penting dalam perkembangan otak. Seseorang yang kekurangan nutrisi terutama selama periode kritis pertumbuhan otak akan mempunyai nilai yang lebih rendah pada tes perbendaharaan kata, pemahaman bacaan, aritmatika dan pengetahuan umum serta mengalamigangguan perkembangan motorik. (7) Pada keadaan stres yang berkepanjangan menyebabkan hilangnya neuron pada hipokampus dan akhirnya memgakibatkan kerusakan memori. ${ }^{(8)}$

Yoga merupakan salah satu metode yang berpengaruh dan dinilai efektif terhadap fungsi kognitif termasuk di dalamnya fungsi memori jangka pendek. Yoga merangsang penurunan aktifitas saraf simpatis dan peningkatan akitifitas saraf parasimpatis yang berpengaruh pada penurunan hormon adrenalin, norepinefrin dan katekolamin serta vasodilatasi pada pembuluh darah yang mengakibatkan transport oksigen ke seluruh tubuh terutama ke otak menjadi lancar sehingga dapat meningkatkan fungsi kognitif. (9) Yoga sebagai sains kuno telah dipraktikkan serta terbukti berhasil dalam meningkatkan fungsi kognitif melalui hatha yoga yang meliputi asana, pranayama, dan meditasi terpimpin dalam posisi terlentang. ${ }^{(10)}$ Penelitian Santhakumari et al. membuktikan terjadinya pemulihan memori yang menurun dan timbulnya perubahan positif metabolit yang berkaitan dengan lobus frontalis pada 5 orang subjek penderita diabetes melitus tipe 2 pria dan wanita berusia antara 35-55 tahun. Latihan dilakukan selama 6 bulan yang terdiri dari Asana dan Pranayama. ${ }^{(11)}$

Masa dewasa dimulai pada usia 18 tahun atau biasa disebut dewasa muda dan akan berakhir pada usia 40 tahun.(7) Menurut ahli psikologi, seorang dewasa muda akan mengalami perkembangan, baik itu perkembangan secara fisik maupun intelektual atau fungsi kognitif serta perkembangan dalam hal bersosialisasi dengan lingkungan sekitarnya. ${ }^{(3)}$ Perkembangan kognitif pada dewasa muda biasanya lebih sistematis dalam hal memecahkan suatu masalah yang berorientasi pada atensi dan kesadaran. Proses kognitif juga bergantung pada fungsi otak suatu individu, seperti memori jangka pendek dan memori jangka panjang. Kemerosotan fungsi otak terutama memori jangka pendek bisa saja terjadi pada dewasa muda, dikarenakan berbagai faktor tertentu. ${ }^{(12)}$

Yoga adalah suatu sistem pendidikan yang terpadu antara tubuh, pikiran, dan jiwa. Yoga dapat meningkatkan kekuatan dan kelenturan, melatih keseimbangan, mengurangi nyeri, melatih pernapasan, melancarkan fungsi organ, ketenangan batin, mengurangi depresi dan stress, menyiagakan tubuh, serta meningkatkan konsentrasi dan kecerdasan. Yoga dilakukan minimal selama 21 hari dalam satu bulan, biasanya sekitar 30 menit dalam satu set yoga. ${ }^{(12)}$ Penelitian tentang manfaat yoga yang lebih difokuskan pada memori jangka pendek untuk dewasa muda masih kurang padahal 
memori jangka pendek merupakan kemampuan yang sangat dibutuhkan agar dapat menghambat proses kemunduran otak. Berdasarkan hal itu maka ingin dilakukan penelitian untyuk melihat pengaruh yoga terhadap memori jangka pendek pada dewasa muda.

\section{METODE}

Subjek penelitian adalah 47 dewasa muda yang dipilih secara consecutive non random sampling. Adapun kriteria inklusi adalah mengikuti latihan yoga secara lengkap selama 21 hari serta kriteria eklusi adalah tidak bisa melakukan yoga, terdapat gangguan pendengaran, terdapat penurunan kesadaran. Perlakuan yang diberikan adalah latihan Hatha yoga dengan durasi 15-30 menit untuk satu set yoga selama 21 hari berturut-turut yang dimonitoring menggunakan absensi kehadiran mengikuti latihan yoga. Penelitian dilakukan di FK Trisakti.

Tabel 1. Digit span test ${ }^{(6)}$

\begin{tabular}{|c|c|c|}
\hline $\begin{array}{c}\text { Angka } \\
\text { maju } \\
\text { (digit } \\
\text { forward } \\
\text { test })\end{array}$ & $\begin{array}{l}\text { Percobaan } 1 \\
\text { (3) } 3-8-6 \\
\text { (4) } 3-4-1-7 \\
\text { (5) } 8-4-2-3-9 \\
\text { (6) } 3-8-9-1-7-4 \\
\text { (7) } 5-1-7-4-2-3-8 \\
\text { (8) } 1-6-4-5-9-7-6-3 \\
\text { (9) } 5-3-8-7-1-2-4-6-9\end{array}$ & $\begin{array}{l}\text { Percobaan } 2 \\
\text { (3) } 6-1-2 \\
\text { (4) } 6-1-5-8 \\
\text { (5) } 5-2-1-8-6 \\
\text { (6) } 7-9-6-4-8-3 \\
\text { (7) } 9-8-5-2-1-6-3 \\
\text { (8) } 2-9-7-6-3-1-5-4 \\
\text { (9) } 4-2-6-9-1-7-8-3-5\end{array}$ \\
\hline $\begin{array}{l}\text { Angka } \\
\text { mundur } \\
(\text { digit } \\
\text { backward } \\
\text { test })\end{array}$ & $\begin{array}{l}\text { (2) } 2-5 \\
\text { (3) } 5-7-4 \\
\text { (4) } 7-2-9-6 \\
\text { (5) } 4-1-3-5-7 \\
\text { (6) } 1-6-5-2-9-8 \\
\text { (7) } 8-5-9-2-3-4-2 \\
\text { (8) } 6-9-1-6-3-2-5-8\end{array}$ & $\begin{array}{l}\text { (2) } 6-3 \\
\text { (3) } 2-5-9 \\
\text { (4) } 8-4-9-3 \\
\text { (5) } 9-7-8-5-2 \\
\text { (6) } 3-6-7-1-9-4 \\
\text { (7) } 4-5-7-8-2-8-1 \\
\text { (8) } 3-1-7-9-5-4-8-2\end{array}$ \\
\hline
\end{tabular}

menggunakan tes Digit Span, di mana komponennya berupa deretan angka maju (Digit Forward) maupun mundur (Digit Backward). Sederetan angka diucapkan oleh peneliti dengan kecepatan satu angka perdetik dan dengan segera sesudahnya, subjek penelitian diminta untuk mengingat dan mengulang deretan angka tersebut baik maju (Digit Forward) maupun mundur (Digit Backward) seperti pada tabel 1.Tes Digit Span dilakukan sebelum yoga yaitu dihari pertama dan sesudah selesai mengikuti yoga dihari ke 21 .

Penilaian berdasarkan hasil penjumlahan dari nilai angka maju ditambah nilai angka mundur. Skala nilai 13-17 adalah memori tinggi, skala nilai 9-12 adalah memori sedang dan skala nilai 0-8 adalah memori rendah.

Analisis data menggunakan program statistik SPSS versi 24. Untuk menilai pengaruh yoga pada kedua kelompok perlakuan maka digunakan uji $\mathrm{T}$ dependent berpasangan dan bila nilai $\mathrm{p}<0.05$ dianggap bermakna dengan 95\% interval kepercayaan.

\section{HASIL}

Tabel 2. Karakteristik subjek penelitian

\begin{tabular}{ll}
\hline \multicolumn{1}{c}{ Variabel } & \multicolumn{1}{c}{$\mathbf{n ( \% )}$} \\
\hline Jenis kelamin & $18(38.3)$ \\
Laki-laki & $29(61.7)$ \\
Perempuan & $2(4.3)$ \\
Usia & $17(36)$ \\
17 tahun & $25(53.3)$ \\
18 tahun & $3(6.4)$ \\
19 tahun & \\
20 tahun & \\
Memori jangka pendek sebelum & $19(40.4)$ \\
yoga & $26(55.3)$ \\
Tinggi & $2(4.3)$ \\
Sedang & \\
Rendah & \\
Memori jangka pendek sesudah & \\
yoga & $28(59.6)$ \\
Tinggi & $19(40.4)$ \\
Sedang & $0(0)$ \\
Rendah &
\end{tabular}

Sebagian besar subjek berjenis kelamin perempuan dengan $53.3 \%$ terdiri dari kelompok usia. Memori jangka pendek sebelum melakukan yoga terbanyak pada kategori sedang sedangkan setelah melakukan yoga terbanyak pada kategori tinggi.

Berdasarkan Tabel 3, didapatkan skor rata-rata memori jangka pendek sesudah melakukan yoga terdapat kenaikan sebesar 1.3 point dibandingkan sebelum melakukan yoga. Berdasarkan hasil uji analisis $\mathrm{T}$ berpasangan didapatkan nilai $\mathrm{p}=0.000(\mathrm{p}<0.05)$ sehingga perbedaan bermakna.

\section{PEMBAHASAN}

Subjek penelitian ini didominasi oleh perempuan dengan kelompok usia tertinggi adalah 19 tahun. Hal ini sesuai dengan penelitian yang dilakukan oleh Gothe et al. terhadap 13 mahasiswa dan staf di Wayne State University, di mana responden perempuan lebih banyak daripada laki-laki dengan usia rata-rata 36 tahun. ${ }^{(13)} \mathrm{Hal}$ ini juga sesuai dengan penelitian yang dilakukan oleh 
Tabel 3. Analisis skor memori jangka pendek sebelum dan sesudah yoga

\begin{tabular}{llccc}
\hline & n & Memori jangka pendek & Nilai $\boldsymbol{p}$ \\
\hline \multirow{2}{*}{ Yoga } & Sebelum & 47 & $11.87 \pm 2.18$ & \\
& Sesudah & 47 & $13.19 \pm 2.02$ & 0.000 \\
\hline
\end{tabular}

Uji T berpasangan: Memori jangka pendek sebelum dan sesudah yoga memiliki $p=0.000$; Data disajikan dalam Mean \pm SD.

Sandy K et al. terhadap 300 mahasiswa Texas University, di mana jumlah responden perempuan lebih banyak daripada laki-laki dengan usia ratarata 23 tahun. ${ }^{(14)}$ Hal ini menunjukkan bahwa responden perempuan lebih memiliki minat besar dalam mengikuti latihan yoga.

Latihan yoga yang diberikan adalah Hatha yoga. Hatha yoga adalah bentuk yoga yang paling umum dipraktikkan di Amerika Utara dan melibatkan praktik postur fisik dalam hubungannya dengan kesadaran napas untuk membantu mengembangkan fokus mental dan untuk menghubungkan pikiran, tubuh, dan jiwa. Hatha yoga membutuhkan upaya yang fokus dalam bergerak melalui posisi mengendalikan tubuh dan bernapas dengan kecepatan tetap. Latihan pernapasan dan meditasi dilakukan untuk menenangkan dan memfokuskan pikiran serta mengembangkan kesadaran diri yang lebih besar. (15)

Latihan yoga tidak hanya terdiri dari peregangan, tetapi juga gerakan yang dinamis yang terikat pada nafas. Yoga dikaitkan dengan berbagai manfaat kesehatan termasuk peningkatan stamina fisik, keseimbangan, fleksibilitas dan relaksasi. Yoga juga menawarkan manfaat psikologis potensial melalui penyertaan pelatihan perhatian yang melibatkan praktik meditasi serta kombinasi dinamis dari kesadaran proprioseptif dan interoseptif. ${ }^{(10)}$ Yoga terbukti memiliki efek psikologis langsung terhadap penurunan kecemasan, depresi dan stres serta perubahan positif dalam persepsi kualitas hidup. Sebuah studi menunjukkan bahwa yoga memiliki efek langsung pada respon sistem saraf simpatis/hipotalamushipofisis-adrenal terhadap stres. ${ }^{(15)}$

Aktivitas otak dikaitkan dengan proses kognitif yang berbeda. Aktivitas otak juga berperan dalam praktik yoga yang berbeda. Yoga adalah modifikasi gaya hidup terbaik yang bertujuan untuk mencapai kesatuan pikiran, tubuh dan jiwa melalui Asana (olahraga), Pranayama (pernapasan) dan meditasi. ${ }^{(16)}$

Penelitian Joice et al. terhadap mahasiswa kedokteran di India menunjukkan bahwa latihan yoga dapat meningkatkan fokus pada sumber daya mental, pemrosesan informasi lebih cepat dan lebih akurat serta juga belajar untuk memegang dan memperbarui informasi secara efektif. Yoga menunjukkan dampak positif pada kesehatan mental dan kesejahteraan, perhatian konsentrasi, memori dan kebugaran fisik. Yoga dapat meningkatkan kemampuan siswa untuk berkonsentrasi dan meningkatkan daya ingat. ${ }^{(16)}$

Terdapat perbedaan skor memori jangka pendeksebelum dan setelah melakukan yoga di mana skor memori jangka pendek mengalami kenaikan setelah melakukan yoga. Menurut penelitian Ciccocioppi L et al., bahwa terdapat peningkatan signifikan dalam menjawab dengan benar dan penurunan jumlah kesalahan dalam kelompok eksperimen yang melakukan yoga. Penemuan ini didasari oleh manfaat yoga terhadap korteks serebri yang menimbulkan perubahan struktur selular berupa neurogenesis, gliogenesis, sinaptogenesis, angiogenesis di neokorteks, hipokampus, dan serebelum serta perubahan struktur molekular berupa peningkatan neurotransmitter serotonin, noradrenalin, dan asetilkolin, dan menginduksi pelepasan faktor neurotropik dan insulin-like growth factor-1. Fisiologi ini diawali oleh aktivitas fisik yang memberikan stimulasi terhadap proliferasi sel glial dan sebagainya. ${ }^{(6)}$ Hippocampus dikenal sangat terlibat dalam proses pembelajaran dan memori. Efek yoga pada volume hippocampus juga selaras dengan temuan dari latihan aerobik. ${ }^{(13)}$

Penelitian yang dilakukan oleh Joice et al. terhadap mahasiswa kedokteran berusia 1723 tahun di India menunjukkan bahwa setelah berlatih yoga ada peningkatan yang signifikan dalam perhatian, konsentrasi dan daya ingat. 
Perubahan ini karena pengembangan kepribadian dan konsentrasi yang lebih tinggi akibat pelatihan yoga. ${ }^{(16)}$ Manfaat fisik dan kognitif yang terkait dengan yoga disebabkan oleh mekanisme aktivasi sistem saraf parasimpatis, konektivitas fungsional yang lebih kuat dalam ganglia basal atau peningkatan aktivasi amigdala. ${ }^{(10)}$ Yoga dapat meningkatkan sensitivitas membran postsinaptik dan penghambatan efektif dari sinyal yang mengganggu, hal ini yang bertanggung jawab atas peningkatan kinerja kognitif. Yoga juga membutuhkan fokus pada titik tertentu di mana orang tersebut belajar mengendalikan pikiran sadar yang dapat membantu meningkatkan konsentrasi. (16)

Penelitian Oken et al. seperti yang dikutip oleh Joice et al. menunjukkan bahwa berlatih yoga dan meditasi meningkatkan tingkat lipatan korteks serebral yang memungkinkan otak untuk memproses informasi segera. Para ilmuwan menduga bahwa lipatan korteks serebral mungkin menjadi alasan untuk membuat otak lebih aktif dalam membentuk ingatan, meningkatkan perhatian, memproses informasi, dan membuat keputusan. ${ }^{(16)}$

Penelitian Kauts Amit et al. menyatakan bahwa siswa yang melakukan yoga menunjukan peningkatan memori jangka pendek dan peningkatan konsentrasi di kelas dibandingkan siswa yang tidak mengikuti yoga. Dikatakan bahwa yoga ataupun meditasi dapat merangsang struktur fisik di dalam otak yang berhubungan dengan fungsi kognitif dan eksekutif, yaitu talamus dan lobus pre-frontal. Dengan adanya peningkatan stimulasi pada kedua bagian otak tersebut, tingkat konsentrasi akan meningkat dan sistem limbik akan semakin susah untuk dirangsang, sehingga memori jangka pendek akan lebih meningkat dan stres menjadi lebih susah timbul. ${ }^{(17)}$

Penelitian Sahasi tahun 1984 seperti yang dikutip oleh Sandy K et al., di mana penelitian tersebut menggunakan lima tes kognitif (pembatalan warna, digit maju, digit mundur, pengakuan dan retensi visual) untuk mempelajari efek yoga selama jangka waktu satu tahun akademik untuk siswa berusia 12 tahun, hasilnya menunjukkan bahwa skor rata-rata kelompok eksperimen lebih tinggi daripada kelompok kontrol. ${ }^{(14)}$
Penelitian oleh Tiwari RK, menyebutkan bahwa siswa laki dan perempuan berusia 14-15 tahun yang melakukan latihan yoga menunjukan peningkatan memori dan peningkatan konsentrasi, menurunkan tekanan psikis serta menjadikan lebih terbuka dalam menerima dan menelaah informasi. (18)

Studi oleh Brunner D et al., mengatakan bahwa terdapat peningkatan memori jangka pendek yang sangat signifikan pada orang yang melakukan yoga. Terlihat bahwa perbedaan memori jangka pendek sangat signifikan setelah melewati lebih dari 5 sesi latihan, meskipun sudah mulai terlihat adanya perbedaan sejak menyelesaikan 1 sesi saja. ${ }^{(10)}$ Studi oleh Jois SN et al., yang dilakukan pada 91 murid asrama terdapat peningkatan memori jangka pendek dan perhatian pada siswa yang melakukan yoga, selain itu juga terdapat peningkatan energi setelah melakukan yoga. ${ }^{(19)}$

Dalam penelitian ini terdapat keterbatasan yaitu tidak menilai faktor lain yang dapat mempengaruhi memori jangka pendek seperti usia, genetik, status gizi serta yang diukur hanya tes digit span yang tidak serta mempresentasikan memori jangka pendek.

\section{KESIMPULAN}

Terdapat perbedaan bermakna antara skor memori jangka pendek sebelum dan sesudah yoga pada dewasa muda.

\section{UCAPAN TERIMA KASIH}

dr. Danny Wiradharma,SH,MS yang telah memberikan bimbingan yoga untuk subjek penelitian.

\section{KONFLIK KEPENTINGAN}

Tidak ada konflik kepentingan antara penulis

\section{REFERENSI}

1. Setyaningsih D. Pengaruh senam otak terhadap kemampuan memori jangka pendek pada anak tuna grahita ringan di SLB Negri Patrang kabupaten Jember (disertasi). Jember. Universitas Jember;2012.

2. Stenberg RJ. Cognitive Psychology. $5^{\text {th }}$ ed. United State of America: Wadsworth; 2009.

3. Santrock JW. Life-span Development: Perkembangan Masa Hidup. Jakarta: 
Erlangga; 1995

4. Desmita. Psikologi Perkembangan. Bandung: PT Remaja Rosdakarya; 2005.

5. Ashcraft MH. Human memory and cognetion. Available at: http://www.researchgate.net/ publication/49302326_Human Memory and cognition. Accessed on May 2,2018

6. Ciccocioppi L, Fabio RA. Improvement of cognitive processes through yoga practice. University of Messiana, 2017. Available at: https://www.researchgate.net/ publication/268278312_Improvement_of_ cognitive_processes_through_yoga_practice. Accessed on June 5,2018.

7. Putranto PL. Pengaruh senam otak terhadap fungsi memori jangka pendek anak dari keluarga status ekonomi rendah (Disertasi). Semarang: Fakultas Kedokteran Universitas Diponegoro;2009.

8. Bullock MR, Povlishock JT, editors. Guidelines for the Management of Severe Traumatic Brain Injury. $3^{\text {rd }}$ ed. New York: Mary Ann Libert; 2007

9. Geyer J, Insel P, Farzin F, et al. Evidence for age-associated cognitive decline from internet game scores: Alzheimer's \& Dementia. Diag Assess \& Dis Monitor2015;1:260-7. DOI:10.1016/j.dadm.2015.04.002.

10. Brunner D, Abramovitch A, Etherton J. A yoga program for cognitive enhancement. PlosOne 2017;12(8):1-12. DOI:10.1371/ journal.pone. 0182366

11. Santhakumari R, Reddy IY, Archana R, et al. Role of yoga in alienating the memory decline and frontal lobe metabolite changes in type 2 diabetes. Int $\mathrm{J}$ Res Ayurveda Pharm 2016;7(1):78-81. DOI:10.7897/22774343.07116

12. Hurlock EB. Psikologi Perkembangan: Suatu Perkembangan Sepanjang Rentang Kehidupan. Jakarta: Erlangga; 1999.

13. Gothe NP, Hayes JM, Temali C, et al. Differences in brain structure and function among yoga practitioners and controls. Frontiers in integrative neuroscience 2018;12:1-9. DOI: 10.3389/fnint.2018.00026

14. Kimbrough S, Balkin R, Rancich A. The effect of inverted yoga positions on short term memory. The online Journal of Sport Psychology 2007;9(2):34-42
15. Gothe NP, Kramer AF, McAuley E. The effect of an 8-week hatha yoga intervention on executive function in older adults. J Gerontol A Biol Sci Med Sci 2014;69(9):1109-16

16. Joice PPS, Manik KA, Sudhir PK. Role of yoga in attention, concentration and memory of medical students. Natl J Physiol Pharm Pharmacol 2018;8(11):1526-28. DOI: 10.5455/njppp.2018.8.0723521082018

17. Kauts A, Sharma N. Effect of yoga on concentration and memory in relation to stress. Inter J of Multidisc Res 2012;2(5):1-14.

18. Tiwari RK. Benefits of yoga practices on high school student's memory and concentration in relation to examination stress. Inter J of Yoga and Allied Sci 2015;4:77-81.

19. Jois SN, D'Souza L, Moulya R. Beneficial effects of superbrain yoga on short-term memory and selective attention of students. Indian J Tradit Knowle. 2017;16:S35-9 